\title{
Passive Transfer of Diabetes from BB/W to Wistar-Furth Rats
}

Steven B. Koevary, Debora E. Williams, R. Michael Williams, and William L. Chick

Biochemistry and Medicine Departments, University of Massachusetts Medical Center, Worcester, Massachusetts 01605; and Department of Medicine, Northwestern University, Chicago, Illinois 60611

\begin{abstract}
Autoimmune diabetes can be transferred to young, diabetes prone $B B / W$ rats by injecting them intravenously with concanavalin A (Con A)-treated spleen cells from acute diabetic BB/W donors. This study describes the transfer of diabetes to the normal Wistar-Furth strain of rats using a similar procedure. For the successful transfer of diabetes it was necessary to immunosuppress recipient animals with a single intraperitoneal injection of cyclophosphamide $24-48 \mathrm{~h}$ before administering Con A-stimulated spleen cells from acute diabetic $B B / W$ rats. Of 68 Wistar-Furth rats immunosuppressed with a dose of 100-150 mg cyclophosphamide/kg body wt, 10 (15\%) became diabetic. None of the control rats receiving either Con Astimulated Wistar-Furth spleen cells $(n=28)$, freshly isolated BB/W spleen cells $(n=14)$, or fresh RPMI medium $(n=11)$ became diabetic. These data indicate that diabetes can be transferred from $\mathrm{BB} / \mathrm{W}$ to Wistar-Furth rats. In addition, they support the hypothesis that cell-mediated immune processes are involved in the development of insulin-dependent diabetes and rule out any absolute requirement for BB-derived genes in the target pancreatic beta cells.
\end{abstract}

\section{Introduction}

Spontaneous diabetes in the nonobese $\mathrm{BB} / \mathrm{W}$ rat is similar to human Type I disease (1). It develops in animals of both sexes between $\sim 60$ and $120 \mathrm{~d}$ of age, and is characterized by the abrupt onset of severe hyperglycemia requiring insulin therapy. Many studies indicate an autoimmune etiology (2-6). An important characteristic finding is insulitis, suggesting cellmediated autoimmunity plays a role in the destruction of beta cells. This possibility is supported by the fact that antilymphocyte serum (7), neonatal thymectomy (8), and bone marrow transplantation (9) either reduce the incidence of or prevent diabetes.

Development of a means for passive transfer of diabetes using $\mathrm{BB} / \mathrm{W}$ cells would provide an important model for investigating the pathogenesis of autoimmune diabetes. Furthermore, it would support the hypothesis that cell-mediated immunity plays a role in the pathogenesis of diabetes in these animals. In this regard, previous studies describe passive transfer

Part of this work was presented at the 43rd Annual Meeting of the American Diabetes Association in June, 1983, and appeared in abstract form. 1983. Diabetes. 32(Suppl. 1):50.

Address correspondence to Dr. Chick, University of Massachusetts Medical Center.

Received for publication 2 November 1984 and in revised form 5 February 1985.

\section{J. Clin. Invest.}

(c) The American Society for Clinical Investigation, Inc

0021-9738/85/06/1904/04 \$1.00

Volume 75, June 1985, 1904-1907 of insulitis from acute diabetic BB rats to immunologically deficient athymic nude mice using spleen and peripheral blood cells (10). However, these studies have proved difficult to repeat (11). Passive transfer of insulitis from BB to X-irradiated BB recipients has also been briefly reported in a few animals (12).

Interestingly, transfer of another autoimmune disease in rodents, experimental allergic encephalomyelitis, is significantly enhanced by culturing donor cells from affected animals with the $T$ cell mitogen concanavalin A (Con A) ${ }^{1}$ (13). Since clearcut transfer of severe diabetes was not possible using freshly isolated cells, we conducted experiments in which spleen cells from acute diabetic BB/W donors were first cultured with Con A. When these cells were injected intravenously into young diabetes prone $\mathrm{BB} / \mathrm{W}$ recipients, $60-90 \%$ developed severe insulitis and hyperglycemia within an average of $12 \mathrm{~d}$ (14).

In this study, we undertook to determine whether diabetes can be transferred to a normal strain of rat. This would provide data on whether beta cells from rats that do not normally develop diabetes can be recognized and selectively damaged by transfer of immune cells from an acute diabetic $\mathrm{BB} / \mathrm{W}$ animal. Since the possibility exists that killing of beta cells through passive transfer involves donor immune cells restricted to the major histocompatibility complex (MHC) (i.e., they must first recognize self-MHC on the beta cells for killing to occur), we chose Wistar-Furth rats (MHC RT1") as our recipients because they share MHC identity with BB rats (15). Because our earlier data suggested an inability to transfer into untreated Wistar-Furth rats, recipients were immunosuppressed with cyclophosphamide. Immunosuppression may be necessary to prevent rejection or suppression of donor cells due to differences in minor histocompatibility antigens.

\section{Methods}

Donor $B B / W$ rats. $\mathrm{BB} / \mathrm{W}$ rats were obtained from the University of Massachusetts Medical School breeding facility (Worcester, MA). The frequency of spontaneous diabetes averages $40-60 \%$ between 60 and $120 \mathrm{~d}$ of age. The disease occurs with equal frequency in both males and females. Donors with acute diabetes were produced by random matings between diabetic males and nondiabetic females. Glycosuria in male and female rats was determined twice a week with Testape (Eli Lilly Co., Indianapolis, IN), and hyperglycemia was verified by determining the plasma glucose concentration with a glucose analyzer (Beckman Instruments, Inc., Fullerton, CA). Con A-stimulated spleen cells from 34 male and female acute diabetic rats between 57 and 111 d of age were used within $4 \mathrm{~d}$ of onset of hyperglycemia. Freshly isolated spleen cells (not stimulated with Con A) from seven acute diabetic rats were used as control donor cells. Additional controls included spleen cells derived from 14 male and female Wistar-Furth rats (Harlan Sprague Dawley, Inc., M. A. Laboratory Animals \& Teklad Diets, Indianapolis, IN) between 2 and 3 mo of age.

1. Abbreviations used in this paper: Con A, concanavalin A; MHC, major histocompatibility complex. 
Animals used in this study were maintained and used in accordance with recommendations in the Guide for the Care and Use of Laboratory Animals, prepared by the Institute of Laboratory Animal Resources, National Research Council (Department of Health, Education, and Welfare publication, National Institutes of Health 78-23, 1978), and guidelines of the Animal Care Advisory Committee of the University of Massachusetts Medical School, Worcester, MA.

Recipient rats. 121 male and female Wistar-Furth rats (Sprague Dawley) between 3 and 4 mo of age served as recipients. Recipient animals were all immunosuppressed with cyclophosphamide (see below). They were divided into four groups receiving one of the following treatments: 1) Con A-stimulated spleen cells from acute diabetic BB/ W donor rats; 2) Con A-stimulated spleen cells from Wistar-Furth donor rats; 3) freshly isolated spleen cells (not Con A-stimulated) from acute diabetic BB/W donor rats; or 4) fresh RPMI medium alone.

Immunosuppression. Cyclophosphamide (Sigma Chemical Co., St. Louis, MO) was dissolved in sterile, isotonic saline. Recipient WistarFurth rats were injected intraperitoneally with doses of $100-150 \mathrm{mg} /$ $\mathrm{kg}$ body wt 1-2 $\mathrm{d}$ before the injection of cells. This dosage range was chosen because it is effective in suppressing cell-mediated immune processes (16). Immunosuppressed rats were maintained on oxytetracycline $(60 \mathrm{mg} / \mathrm{dl}$, Terramycin; Pfizer Chemicals Div., Pfizer Inc., New York, NY) in hooded cages to reduce the likelihood of infection.

Glucose determinations and food consumption. Recipients from each of the four treatment groups were screened for glycosuria three times weekly. In addition, multiple determinations of plasma glucose concentrations were performed in animals from three of the treatment groups as follows: 1) recipients of Con A-stimulated BB/W cells had determinations twice a week, and then daily following a positive urine glucose test; 2) six recipients of Con A-stimulated Wistar-Furth cells had determinations twice a week, while remaining animals had a determination at the time of sacrifice $30 \mathrm{~d}$ after injection of cells; 3 ) recipients of freshly isolated $\mathrm{BB} / \mathrm{W}$ cells had determinations twice a week for three weeks after injection of cells.

To provide a rough measure of health status, the amount of food consumed by immunosuppressed rats was measured and was compared with that of age-matched nonimmunosuppressed animals. This was done by weighing the food pellets daily in cages that housed four rats each. Three cages of animals were studied in each group.

Spleen cell culture. The cell culture procedure has been previously described (14). Briefly, spleens from acute diabetic BB/W and control Wistar-Furth rats were removed aseptically and teased apart in RPMI 1640 medium (Gibco Laboratories, Grand Island, NY) containing 10\% heat-inactivated fetal calf serum (HyClone Laboratories, Sterile Systems, Inc., Logan, UT), $5 \mathrm{mM}$ glutamine, $5 \times 10^{-5} \mathrm{M} \beta$-mercaptoethanol, and $400 \mathrm{U} / \mathrm{ml}$ sodium penicillin. $100-300 \times 10^{6}$ cells were incubated in $150 \mathrm{ml}$ RPMI 1640 containing $5 \mu \mathrm{g} / \mathrm{ml}$ Con A (Mile-Yeda, Rehovot, Israel). Incubations were carried out in flasks (Costar, Data Packaging Corp., Cambridge, MA) at $37^{\circ} \mathrm{C}$ in a humidified atmosphere of $5 \%$ $\mathrm{CO}_{2} / 95 \%$ air for $72 \mathrm{~h}$. Cells were harvested by centrifugation, and the pellet was washed twice with serum-free RPMI 1640 medium. Cell numbers were determined using a Coulter Counter (Coulter Electronics Inc., Hialeah, FL). The cultured cells were injected into the tail veins of recipient animals using a 25-gauge needle with a cannula (Minicath25; Deseret Co., Sandy, UT). Each recipient received one half the yield from a single spleen $\left(\sim 50-100 \times 10^{6}\right.$ cells) in $1 \mathrm{ml}$ of serum-free RPMI 1640 medium. Animals receiving freshly isolated cells were injected with similar numbers of cells. One group of control animals received $1 \mathrm{ml}$ of fresh serum-free RPMI medium without cells.

Morphology. Wistar-Furth recipients that became diabetic after administration of $\mathrm{BB} / \mathrm{W}$ cells were killed at the time of onset of hyperglycemia to document the presence of insulitis. In addition, five control rats receiving Wistar-Furth cells and five moribund rats receiving high dose cyclophosphamide $(150 \mathrm{mg} / \mathrm{kg})$ were studied. Pancreatic tissue was fixed in Bouin's solution and embedded in paraffin. $5-\mu \mathrm{m}$ sections were stained with hematoxylin and eosin.

Statistics. Significant differences between experimental and control groups were determined using the Chi square test. A computer program (Minitab) was used for this purpose.

\section{Results}

\section{Spleen cell culture}

After $3 \mathrm{~d}$ in culture with Con A, blast cells, distinguished by their large size and regular spherical shape, were seen in all cultures. However, a greater percentage seemed to be present in cultures from Wistar-Furth compared with cultures from acute diabetic $\mathrm{BB} / \mathrm{W}$ rats. The number of cells harvested from the $\mathrm{BB} / \mathrm{W}$ cultures after $3 \mathrm{~d}$ ranged from $\sim 30 \%$ lower to $10 \%$ higher than the initial count. On the other hand, the number of cells harvested from the control Wistar-Furth cultures fell within $\pm 10 \%$ of the initial count.

\section{Effects of cyclophosphamide treatment}

Cyclophosphamide produced significant morbidity and mortality that was dose dependent. Approximately $50 \%$ of animals injected with a dose of $150 \mathrm{mg} / \mathrm{kg}$ died within $2 \mathrm{wk}$. Since in our previous study (14) we could not transfer diabetes in $<7$ $\mathrm{d}$, those animals that died within $7 \mathrm{~d}$ after injection of cells $(n=3)$ were not included in our results.

Food consumption in animals treated with cyclophosphamide was markedly reduced. While the average consumption in untreated Wistar-Furth rats was $72.5 \pm 6.5 \mathrm{~g}$ (mean $\pm \mathrm{SE}) / \mathrm{d}$, that in cyclophosphamide-treated rats was $25.2 \pm 3.2 \mathrm{~g} / \mathrm{d}$.

\section{Passive transfer}

Rats receiving cells from acute diabetic $B B / W$ donors. Freshly isolated spleen cells from acute diabetic rats, when injected into cyclophosphamide-treated Wistar-Furth recipients, did not result in hyperglycemia (Table I). Plasma glucose determinations during the $3 \mathrm{wk}$ after the injection of cells never exceeded $136 \mathrm{mg} / \mathrm{dl}$, and the average glucose concentration was $119 \pm 4$ (mean \pm SE, $n=14$ rats) at the time of sacrifice.

When Con A-stimulated spleen cells from acute diabetic $\mathrm{BB} / \mathrm{W}$ donors were injected into cyclophosphamide-treated Wistar-Furth rats, hyperglycemia developed in $15 \%$ of the recipients (Table I). However, this occurred only in those rats receiving cyclophosphamide at a dose of $130 \mathrm{mg} / \mathrm{kg}$ or more. The mean interval from transfer to onset of hyperglycemia was $12 \pm 1$ (SE) d, while the mean plasma glucose concentration from onset to sacrifice was $446 \pm 18$ (SE) $\mathrm{mg} / \mathrm{dl}$ (Table II). Plasma glucose concentrations were normal until onset, with a mean of $122 \pm 3 \mathrm{mg} / \mathrm{dl} 1-3 \mathrm{~d}$ before onset.

Control rats receiving Con A-stimulated Wistar-Furth spleen cells or RPMI media. Control rats receiving fresh RPMI media remained aglycosuric throughout the experiment and were killed 3-4 wk post injection of cells (Table I). Rats receiving Wistar-Furth spleen cells similarly remained aglycosuric and had a plasma glucose concentration of $121 \pm 2 \mathrm{mg} / \mathrm{dl}$ at sacrifice (Table I). Six of these animals had twice weekly plasma glucose determinations during the $30 \mathrm{~d}$ after injection of spleen cells. The highest value obtained was $151 \mathrm{mg} / \mathrm{dl}$, and the average plasma glucose concentration was $122 \pm 2 \mathrm{mg} / \mathrm{dl}$ (mean $\pm \mathrm{SE}$ ).

\section{Morphology}

Sections of pancreas from seven Wistar-Furth rats that became diabetic as the result of passive transfer revealed varying degrees of lymphocytic insulitis similar to that seen in spontaneously diabetic $\mathrm{BB} / \mathrm{W}$ rats. Islets were distorted by the presence of numerous inflammatory cells permeating the interior and surrounding the periphery of the islets. Mononuclear cells were also seen around some ducts and small vessels. Pancreatic sections from Wistar-Furth recipients that received 
Table I. Passive Transfer of Diabetes to Immunosuppressed Wistar-Furth Rats

\begin{tabular}{|c|c|c|c|c|c|c|c|}
\hline \multicolumn{2}{|c|}{$\begin{array}{l}\text { Recipients of Con A- } \\
\text { stimulated BB/W spleen } \\
\text { cells }\end{array}$} & \multirow[b]{2}{*}{$\begin{array}{l}\text { Number becoming } \\
\text { diabetic }\end{array}$} & \multicolumn{4}{|c|}{$\begin{array}{l}\text { Recipients of freshly isolated BB/W spleen cells, Con A-stimulated Wistar-Furth spleen } \\
\text { cells, or RPMI medium }\end{array}$} & \multirow[b]{2}{*}{$\begin{array}{l}\text { Number becoming } \\
\text { diabetic }\end{array}$} \\
\hline $\begin{array}{l}\text { Cyclophos- } \\
\text { phamide } \\
\text { dose }\end{array}$ & $\begin{array}{l}\text { Number of } \\
\text { recipient } \\
\text { animals }\end{array}$ & & $\begin{array}{l}\text { Cyclophos- } \\
\text { phamide } \\
\text { dose }\end{array}$ & $\begin{array}{l}\text { Number of animals } \\
\text { receiving Wistar- } \\
\text { Furth cells }\end{array}$ & $\begin{array}{l}\text { Number of animals } \\
\text { receiving } \mathrm{BB} / \mathrm{W} \\
\text { cells }\end{array}$ & $\begin{array}{l}\text { Number of animals } \\
\text { receiving RPMI } \\
\text { medium }\end{array}$ & \\
\hline $\mathrm{mg} / \mathrm{kg}$ & & & $m g / k g$ & & & & \\
\hline 100 & 10 & 0 & 100 & 6 & 0 & 7 & 0 \\
\hline 125 & 4 & 0 & 130 & 4 & 0 & 0 & 0 \\
\hline 130 & 4 & 2 & 135 & 2 & 0 & 0 & 0 \\
\hline 135 & 14 & 1 & 140 & 1 & 0 & 0 & 0 \\
\hline 140 & 3 & 0 & 150 & 15 & 14 & 4 & 0 \\
\hline 150 & 33 & 7 & & & & & \\
\hline Total & 68 & $10(15 \%)^{*}$ & & 28 & 14 & 11 & 0 \\
\hline
\end{tabular}

* Significance compared with all 53 control animals, $P<0.001$; control animals receiving Con A-stimulated Wistar-Furth cells, $P<0.05$. Plasma glucose concentrations in cyclophosphamide-treated control Wistar-Furth rats receiving Con A-stimulated Wistar-Furth cells or freshly isolated $\mathrm{BB} / \mathrm{W}$ spleen cells were $121 \pm 2$ and $119 \pm 4 \mathrm{mg} / \mathrm{dl}($ mean $\pm \mathrm{SE})$, respectively.

Wistar-Furth cells cultured with Con A appeared normal ( $n$ $=5$ ). Sections from Wistar-Furth animals that received cyclophosphamide alone $(150 \mathrm{mg} / \mathrm{kg}$ body $\mathrm{wt})$ were also free of insulitis.

\section{Discussion}

The present data indicate that hyperglycemia and insulitis can be successfully transferred to the normal Wistar-Furth rat strain using Con A-stimulated spleen cells from acute diabetic

Table II. Time Intervals and Glucose Concentrations in Animals Becoming Diabetic

\begin{tabular}{llll}
\hline $\begin{array}{l}\text { Animal } \\
\text { number }\end{array}$ & $\begin{array}{l}\text { Cyclophos- } \\
\text { phamide dose }\end{array}$ & $\begin{array}{l}\text { Interval from transfer } \\
\text { to onset of } \\
\text { hyperglycemia* }\end{array}$ & $\begin{array}{l}\text { Plasma glucose } \\
\text { concentration from } \\
\text { onset of } \\
\text { hyperglycemia to } \\
\text { sacrifice }\end{array}$ \\
\hline & $m g / k g$ & $d$ & $m g / d l$ \\
1 & 130 & 10 & $414(2)$ \\
2 & 130 & 10 & $415(2)$ \\
3 & 135 & 14 & $405(5)$ \\
4 & 150 & 8 & $446(2)$ \\
5 & 150 & 10 & $442(1)$ \\
6 & 150 & 15 & $423(2)$ \\
7 & 150 & 14 & $476(2)$ \\
8 & 150 & 14 & $477(2)$ \\
9 & 150 & 11 & $514(2)$ \\
10 & 150 & 12 & $452(2)$ \\
Mean \pm SE & $144 \pm 3$ & $12 \pm 1$ & $446 \pm 18$ \\
& & &
\end{tabular}

* Hyperglycemia denotes a plasma glucose concentration $>200$ $\mathrm{mg} / \mathrm{dl}$.

¥ Values are means; daily plasma glucose determinations were made from the time of onset until sacrifice 1-5 d later. The number of determinations for each animal is in parentheses.
BB/W donors. Con A-stimulated cells were used because our previous studies (14) suggested that freshly isolated spleen cells were ineffective in transferring diabetes. Indeed, this Con A requirement was confirmed by our inability to transfer diabetes into immunosuppressed Wistar-Furth recipients of freshly isolated acute diabetic spleen cells. It also proved necessary to immunosuppress recipients with high doses of cyclophosphamide for effective transfer of diabetes. In addition to minor histoincompatibilities between Wistar-Furth and $\mathrm{BB} / \mathrm{W}$ rats, suppressor cells in Wistar-Furth recipients could interfere with the activity of the transferred cells. Indeed, a deficiency in suppressor cells (17) has been proposed as a contributing factor in the spontaneous expression of diabetes in $\mathrm{BB} / \mathrm{W}$ rats. Cyclophosphamide was chosen for immunosuppression because it inhibits $\mathrm{T}$ lymphocyte subsets, including suppressor cells (16).

There was a significant mortality associated with the use of high doses of cyclophosphamide. Furthermore, diminished food intake showed that even animals that survived were not in ideal health. Blood glucose values (not shown) of moribund immunosuppressed rats at sacrifice, however, were normal. In addition, pancreatic morphology was normal, with no evidence of insulitis. Furthermore, plasma glucose concentrations in control rats receiving Con A-stimulated Wistar-Furth or freshly isolated acute diabetic BB/W spleen cells remained normal throughout the experiment. Overall, this model was useful to answer the questions addressed, but it is not entirely satisfactory for routine study. Interestingly, Like et al. recently found (18) that transfer of diabetes from acute diabetic $\mathrm{BB} / \mathrm{W}$ donors to inbred diabetes-resistant $\mathrm{BB} / \mathrm{W}$ rats (W-line) required the use of $150 \mathrm{mg} / \mathrm{kg}$ cyclophosphamide. Strains with diabetes genes bred into defined inbred backgrounds should overcome the problem of requiring high doses of cyclophosphamide.

An important question to be answered regards the specific cell type or types responsible for transfer. Specific $T$ cell subset antibodies can be used for transfer when the aforementioned congenic lines are available. Since the MHC-restricted cytotoxic $T$ lymphocyte is one possible candidate for the ultimated effector cell, passive transfer experiments using recipient strains 
that do not share the RT1" MHC of the BB rat may provide important information needed to answer this question.

Studies of islet transplants to BB rats (9) are also relevant to this question. Recent results of Weringer and Like (19) show insulitis in isolated islets from various non-MHC compatible strains when these islets are transplanted under the renal capsule of diabetic $\mathrm{BB} / \mathrm{W}$ rats. Since these animals retained a $\mathrm{BB} / \mathrm{W}$ diabetic pancreas and had incompatible tissue grafts, it cannot be definitively concluded that the insulitis seen was associated with the beta cell cytotoxicity that leads to spontaneous diabetes. Preliminary results from our laboratory suggest an inability to transfer diabetes into the non-MHC compatible New England Deaconess Hospital strain (RT1 $1^{\mathrm{B}}$ ) (20) $(n=24)$.

Transfer studies using rats immunosuppressed with agents that obliterate all $T$ cells could be useful in determining whether the immune cells responsible for beta cell destruction are present in the donor inoculum, or whether endogenous $T$ cells need to be recruited. Similarly, studies of $T$ cell lines developed from diabetic rats may be useful in this regard.

\section{Acknowledgment}

We thank Kathy Meunier for her skillful technical assistance. Dr Koevary is the recipient of a postdoctoral fellowship from the Juvenile Diabetes Foundation.

This work was supported in part by National Institutes of Health grants AM30846, AM32520, and AM26733.

\section{References}

1. Like, A. A., L. Butler, R. M. Williams, M. C. Appel, E. J. Weringer, and A. A. Rossini. 1982. Spontaneous autoimmune diabetes mellitus in the BB rat. Diabetes. 31:7-13.

2. Nakhooda, A. F., A. A. Like, C. J. Chappel, C. N. Weir, and E. B. Marliss. 1978. The spontaneously diabetic Wistar rat. Studies prior to and during development of the overt syndrome. Diabetologia. 14:199-207.

3. Dyrberg, T., A. F. Nakhooda, S. Baekkeskov, A. Lernmark, P. Poussier, and E. B. Marliss. 1982. Islet cell surface antibodies and lymphocyte antibodies in the spontaneously diabetic BB Wistar rat. Diabetes. 31:278-281.

4. Elder, M., and N. Maclaren. 1983. Identification of profound peripheral $\mathrm{T}$ lymphocyte immunodeficiencies in the spontaneously diabetic BB rat. J. Immunol. 130:1723-1730.

5. Baekkeskov, S., T. Dyrberg, and A. Lernmark. 1984. Autoantibodies to a 64-kilodalton islet cell protein precedes the onset of spontaneous diabetes in the BB rat. Science (Wash. DC). 224:13481350.

6. Jackson, R., N. Rossi, T. Crump, B. Haynes, and G. S. Eisenbarth. 1981. The BB diabetic rat: profound T-cell lymphocytopenia. Diabetes. 30:887-889.

7. Like, A. A., A. A. Rossini, D. L. Guberski, M. C. Appel, and R. M. Williams. 1979. Spontaneous diabetes mellitusi reversal and prevention in the BB/W rat with antiserum to rat lymphocytes. Science (Wash. DC). 206:1421-1423.

8. Like, A. A., R. M. Williams, E. Kislauskis, and A. A. Rossini. 1981. Neonatal thymectomy prevents spontaneous diabetes in the BioBreeding/Worcester (BB/W) rat. Clin. Res. 29:542a. (Abstr.)

9. Naji, A., W. K. Silvers, H. Kimura, A. O. Anderson, and C. F. Barker. 1983. Influence of islet and bone marrow transplantation on the diabetes and immunodeficiency of BB rats. Metab. Clin. Exp. 32(Suppl. 1):62-68.

10. Poussier, P., A. F. Nakhooda, A. A. F. Sima, and E. B. Marliss. 1983. Passive transfer of insulitis and lymphopenia in the BB rat. Metab. Clin. Exp. 32(Suppl. 1):73-79.

11. Rossini, A. A., J. P. Mordes, R. M. Williams, A. Muldoon, and A. A. Like. Failure to transfer insulitis to athymic recipients using BB/W rats' lymphoid tissue transplants. Metab. Clin. Exp. 32(Suppl. 1):80-82.

12. Naji, A., W. K. Silvers, and C. F. Barker. 1983. Autoimmunity and type 1 (insulin-dependent) diabetes mellitus. Transplantation (Baltimore). 36:355-361.

13. Panitch, H. S., and D. E. McFarlin. 1977. Experimental allergic encephalomyelitis: enhancement of cell mediated transfer by concanavalin A. J. Immunol. 119:1134-1137.

14. Koevary, S., A. Rossini, W. Stoller, R. M. Williams, and W. Chick. 1983. Passive transfer of diabetes in the BB/W rat. Science (Wash. DC). 220:727-728.

15. Howard, J. C. 1983. The major histocompatibility complex of the rat: a partial review. Metab. Clin. Exp. 32:41-50.

16. Shand, F. L. 1979. The immunopharmacology of cyclophosphamide. Int. J. Immunopharmacol. 1:165-171.

17. Like, A. A., R. M. Forster, B. A. Woda, and A. A. Rossini. 1983. T-cell subsets in islets and lymph nodes of Bio Breeding/ Worcester rats. Diabetes. 32(Suppl. 1):51a. (Abstr.)

18. Like, A. A., E. J. Weringer, A. Holdash, P. McGill, D. Atkinson, and A. A. Rossini. 1985. Adoptive transfer of autoimmune diabetes mellitus in Biobreeding/Worcester (BB/W) inbred and hybrid rats. $J$. Immunol. In press.

19. Weringer, E. J., and A. A. Like. 1984. Immune destruction of islets transplanted into Biobreeding/Worcester $(\mathrm{BB} / \mathrm{W})$ rats. Diabetes. 33(Suppl. 1):61a. (Abstr.)

20. Reintgen, D., B. Croker, C. Vervaert, J. Feldman, and H. F. Seigler. 1980. Immunological consequences of transplanting rat insulinomas. Transplantation (Baltimore). 30:16. 